УДК 616.72-002-02:[616.39+616.74-007.23]-053.9](048.8)

DOI: http://dx.doi.org/10.15674/0030-598720213101-106

\title{
Sarcopenia, sarcopenic obesity and osteoarthritis
}

\author{
N. V. Dedukh, N. V. Zaverukha, M. A. Bystrytska, N. M. Yakovenchuk \\ ${ }^{1}$ SI «D. F. Chebotarev Institute of Gerontology National Academy of Medical Sciences of Ukraine», Kyiv \\ ${ }^{2}$ Sumy Regional Clinical Hospital. Ukraine
}

Sarcopenia is considered an important geriatric syndrome, the manifestations of which lead to impaired quality of life and increased mortality. Sarcopenia is a disease associated with decreased muscle mass and strength. Sarcopenic obesity is manifested by an increase in subcutaneous or visceral fat, fatty degeneration of muscles, and is also accompanied by impaired muscle function. After the age of 40 , an average of $8 \%$ loss of muscle mass is noted, and by the age of 80 this value can reach $50 \%$. The review examined the relationship between sarcopenia, sarcopenic obesity, and osteoarthritis (OA). Many exogenous and endogenous factors influence the development and course of OA. Based on the study of mechanisms of cellular and molecular profiles, the specific features for these frequently coexisting pathologies have been identified. The review presents the molecular mechanisms in the development of sarcopenia, sarcopenic obesity and osteoarthritis. Increased fat mass is manifested by increased adipogenesis, expression of inflammatory molecules (leptin, adiponectin, interleukin-1 (IL-1), IL-1b, IL-6 and tumor necrosis factor $\alpha$ ) that contribute to chronic low-grade systemic inflammation and negatively affect muscle and joint quality. The relationship between elevated levels of myostatin and muscle weakness as well as myostatin accumulation in synovial fluid and severity of osteoarthritis was considered. Some common mechanisms in the development of sarcopenia and OA were noted: the influence of oxidative stress, systemic chronic inflammation, and disruption of the signaling pathway of bone morphogenetic proteins. Based on the analysis of associations between sarcopenia, sarcopenic obesity, and $O A$, population-based studies have revealed a high prevalence of knee $O A$ with an increased risk among men with sarcopenic obesity. Women with sarcopenia and sarcopenic obesity had a high risk of knee OA in both groups. The review reviewed the prevention and treatment of the combined pathology, in particular the effect of sarcopenia on the results of total joint arthroplasty in patients with $O A$. In general, sarcopenia, sarcopenic obesity, and $O A$ can be considered as concomitant age-associated diseases that jointly affect quality of life and life expectancy.
Саркопенія - захворювання, пов'язане зі зниженням м'язової маси та сили. Саркопенічне ожиріння проявляється збільшенням вмісту підшкірного або вісиерального жиру, жировим переродженням м'язів і порушенням м'язової функиії. Після 40 років визначають втрату м'язової маси в середньому на $8 \%$, а у 80 років ией показник може досягти $50 \%$. В огляді розглянуто взаємозв'язок між саркопенією, саркопенічним ожирінням й остеоартрозом (OA). На розвиток і перебіг ОА впливає безліч екзогенних і ендогенних факторів, на основі дослідження механізмів клітинних і молекулярних профілів, виявлено особливості циих патологій, які часто перебігають у поєднанні. Наведено молекулярні механізми розвитку саркопенічного ожиріння й остеоартрозу. Збільшення жирової маси проявляється підвищенням адіпогенезу, експресією молекул запалення (лептину, адипонектину, інтерлейкіну-1, -1b, -6 і фактора некрозу пухлини $\alpha$ ), щзо сприяе підтримці хронічного низькоградієнтного системного запалення та негативно впливає на якість м'язів і суглобів. Розглянуто зв'язок між підвищеним рівнем міостатину та слабкістю м'язів, а також накопиченням міостатину в синовіальній рідині та важкістю остеоартрозу. Виявлено загальні механізми в розвитку саркопенії й ОА - вплив оксидативного стреcy, системне хронічне запалення, порушення сигнального шляху кісткових морфогенетичних білків. На основі аналізу асочіацій між саркопенією, саркопенічним ожирінням та OA в популяційних дослідженнях встановлено високу поширеність ОА колінного суглоба з підвищеним ризиком серед чоловіків із саркопенічним ожирінням. У жінок із саркопенією та саркопенічним ожирінням ризик ОА колінного суглоба був високим в обох групах. Розглянуто питання профілактики та лікування поєднаної патології, зокрема вплив саркопенії на результати тотального ендопротезування великих суглобів у пачієнтів з ОА. Загалом, саркопенію, саркопенічне ожиріння й ОА можна розглядати як супутні вік-асоційовані захворювання, які спільно впливають на якість і тривалість життя. Ключові слова. Саркопенія, саркопенічне ожиріння, остеоартроз, м'язова маса, якість життя. 
Key words. Sarcopenia, sarcopenic obesity, osteoarthritis, lean mass, quality of life

In recent years, medical scientists have been focusing on the association between sarcopenia and osteoarthritis (OA) [1]. This connection is considered from different positions: as coexisting conditions, sarcopenia as a risk factor for the progression of OA or OA as a risk factor for sarcopenia $[2,3]$.

Osteoarthritis is manifested by an alteration of intra- and periarticular soft tissue with maximum severity in the articular cartilage and subchondral bone. Muscles which are associated with the joint provide it function and stability. Some studies shows that knee extensor muscle weakness is a risk factor for the development of gonarthrosis [4]. Thus, OA is an organ failure of the entire synovial joint with an important functional role of muscles [5].

Sarcopenia is defined as a progressive and generalized disease of skeletal muscle associated with loss of muscle strength, mass (lean mass) and function disorder [6]. This condition is associated with physiological aging or as a result of physical inactivity, endocrine diseases, and inadequate nutrient intakes, etc. After 40 years of age muscle mass decreases approximately $1 \%$ per year, and by the age of 80 it can reach over $50 \%$ [7].

Patients with osteoarthritis often have not only sarcopenia, but also obesity, as well as a combination of sarcopenia and obesity - sarcopenic obesity, but there is no clear understanding of the connection between these conditions [8]. If patients with sarcopenia look mostly thin, then with sarcopenic obesity they look obese. In patients with OA the combination of sarcopenic obesity leads to an increase in the effect of sarcopenia, which significantly worsens the quality of life and increases the risk of mortality [9]. Sarcopenic obesity in the adult population occurs from 0 to $41 \%[10]$ or according to the current data of studies presented in the literature, the prevalence varies from $3 \%$ to $35.4 \%$ in different populations. The data discrepancy may be due to the different methods for assessing and classification of obesity by body mass index (cut-off values in Asian populations are $\geq 25$ or $\geq 27.5$, and in populations of North America and Europe $\geq 30$ ) [11].

Sarcopenic obesity is an increase in the subcutaneous or visceral fat content, accompanied by a decrease in muscle mass, which is a strong factor in the development and progression of osteoarthritis $[11,12]$.

A vicious circle is formed in patients with OA: patients try to avoid physical activity due to pain and joints dysfunction, which leads to a decrease in musc- le strength, the development of overweight, or obesity. Increased adipogenesis accelerates muscle loss, leads to the development of sarcopenic obesity, and acts as a risk factor for $\mathrm{OA}[7,11,13]$.

General mechanisms of $O A$ and sarcopenia

The combination of sarcopenia and OA among women over 65 years old is quite high and is equal to $31.45 \%$ and increases with age, reaching $61.54 \%$ in patients over 85 years old [14]. According to data of the other authors, based on the result of SARC-F questionnaire, the highest prevalence of risk of sarcopenia was detected in patients with hip OA $72.3 \%$, compared with $63.2 \%$ in the population with knee OA and $71.3 \%$ with OA of other joints [15].

The mechanisms for the development of sarcopenia, sarcopenic obesity, and OA are common including aging, overweight, genetic and other exogenous and endogenous factors [11] (figure). Physical activity decreases with age. Also changes occurs in hormonal background like in the biosynthesis and metabolism of insulin, sex hormones, parathyroid hormone and vitamin D, the insulin-like growth factor-1 [39], which are common links in muscle and joint tissue disorders.

Age-related loss of muscle mass is accompanied by disorganization of muscle fibers, a decrease in satellite cells, type II fibers (fast) and an increase in the structure of skeletal muscles type I fibers (slow); increased lipid infiltration, which leads to a decrease in muscle strength and increased fatigue [16].

The increase in fat mass is manifested by an increase in adipogenesis, inflammatory molecules expression (leptin, adiponectin, interleukin-1 (IL-1), IL-1 beta, IL-6 and tumor necrosis factor alpha), which contributes to a chronic low-level systemic inflammation and negatively affects the quality muscle. Progressive loss of skeletal muscle mass are occurred [17, 18, 19]. Muscle atrophy leads to an increase of joint load and the formation of deformity of bone ends and articular cartilage fissures with a low level of regeneration.

Oxidative stress is a significant risk factor in a combination of OA and sarcopenia. Free radicals mediate and affect articular cartilage, intra-articular and para-articular tissues, including muscles, increasing degenerative tissue disorders [20, 21]. The accumulation of active oxygen/nitrogen species is considered as the main reasons for the development of muscular dystrophy and sarcopenia, since muscles are susceptible to oxidative stress, and mitochondrial dysfunction is considered as the main mechanism 
of aging of skeletal muscles and the development of sarcopenia, as well as damage to articular tissues. Oxidative stress is a cause of synovial inflammation, degradation of articular cartilage, apoptosis of chondrocytes, its negative effect leads to a decrease in the biosynthesis of matrix molecules and dysfunction of the subchondral bone [21-23]. Aging of cells and degenerative disorders in skeletal muscle cells and articular cartilage under the influence of reactive oxygen species are accompanied by the accumulation of single-strand breaks in telomere regions, leading to a decrease in their length $[24,25]$.

Nuclear factor erythroid 2-related factor 2 (Nrf2) is involved in the regulation of antioxidant genes. The influence of OA on the development of sarcopenia can be carried out through Nrf2, which protects the muscle from the toxic effects of free radicals [26]. The sedentary lifestyle of patients with OA leads to dysfunction of Nrf2-mediated antioxidant response which ultimately is a risk factor for the development of skeletal muscle atrophy.

The key mediators of muscle and bone homeostasis, play bone morphogenetic proteins (BMP) and myostatin signaling pathways [27]. Myostatin, myokine protein, belongs to the transforming growth factor $\beta$ (TGF $\beta$ ). Mostly it is expressed in muscle tissue, negatively regulating growth of skeletal muscles and their regeneration, competing for binding of BMP receptor and Smad4 activation, which violated the quality of muscle. In addition, myostatin is expressed by synovial membrane cells and its concentration in se- rum and synovial fluid correlates with the severity of knee OA [28].

Expression of BMP-2, BMP-4, BMP-7, myostatin, phosphorylated small mothers against decapentaplegic was studied by the methods of immunohistochemistry) Smads1-5-8 proteins (regulating muscle regeneration by transmitting BMP signals), Pax7 and myogenen in muscle biopsy samples obtained during total hip arthroplasty in patients with coxarthrosis [27]. It was detected that in patients with OA, the expression of BMP-2 and 7 in sarcopenic muscles was three times higher than BMP-4 and contained numerous phosphorylated Smad1/5-8 positive nuclei, which indicates the specificity of cellular and molecular characteristics. At the same time, an increase in the expression of myostatin and cytoplasmic Smad was accompanied by a decrease in satellite cells involved in muscle tissue regeneration, as well as Smad 2, 4, 7.

Searching for associations between sarcopenia, sarcopenic obesity and osteoarthritis in population studies

In one of the largest longitudinal studies (1 653 subjects) was studied the risk of knee OA depending on the type of body composition, measured using Dualenergy X-ray absorptiometry (DXA): normal, obesity, sarcopenic obesity and sarcopenia. After the observation of patients for 60 months, the authors, revealed an increased risk of radiographic knee OA among women and men with obesity and sarcopenic obesity [29]. They concluded that weight loss at the cost of fat content and increased muscle mass are important elements in the prevention and treatment of knee OA.

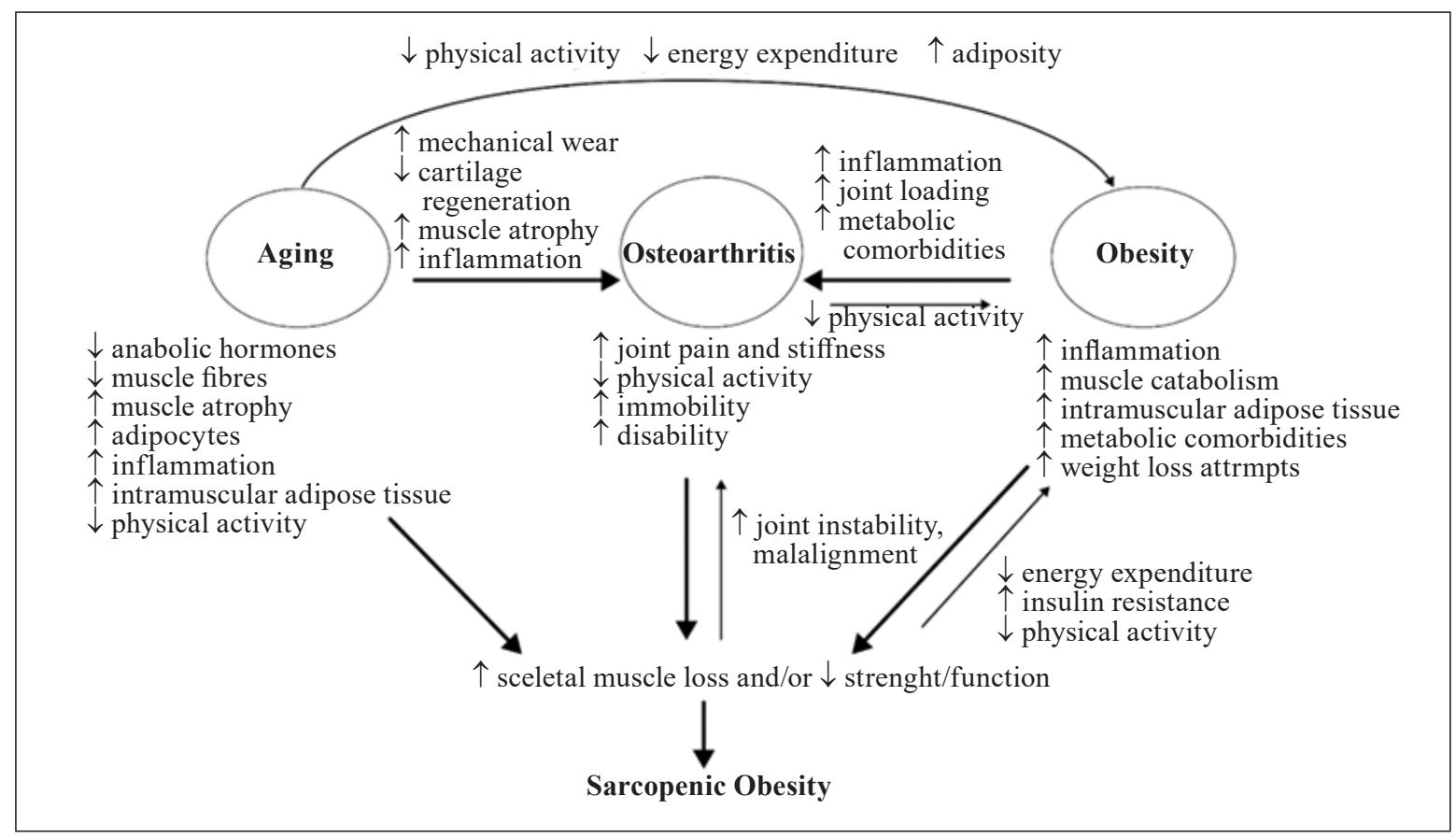

Figure. The connection between age, sarcopenic obesity and osteoarthritis [adapted from 11] 
A 2018 scoping review of the link between body composition and osteoarthritis of the knee or hip shows that this is an essential issue, as 796 publications of original research results were found between 2005 and 2017, including 118 full-text articles, but only 11 have been included to research [11]. According to the literature data, the muscle weakness, low skeletal muscle mass or sarcopenia in combination with obesity affect the course and severity of the OA of the lower extremity.

The high prevalence of OA of the knee joint among persons with sarcopenic obesity is presented in another scientific work [17]. The studied groups of subjects with obesity and sarcopenic obesity had the same body weight, however, the group of sarcopenic obesity was more closely associated with knee OA, which, according to the authors, confirms the importance of the systemic metabolic effect of obesity.

The association between sarcopenia and OA was determined in terms of appendicular muscle mass index (AMI), physical function (timing and running, 30-second sit-to-stand test, 40 Meter fast paced walk test and grip strength) and self-reported fatigue (multivariate assessment of fatigue (Multidimensional Assessment of Fatigue, MAF) and Visual Analogue Scale (VAS)). The authors found no association of sarcopenia with OA in evaluation AMI scores and self-esteem, fatigue, or physical activity [30]. Moderately strong association of OA and sarcopenia has been found in subjects with high body fat concentration. In another study in $41-56 \%$ of patients with OA was detected fatigue and $10 \%$ of subjects experienced severe fatigue [6].

Another study, based on an assessment of 159 women with OA ((74 \pm 6$)$ years), showed that pain intensity (VAS) and muscle function (short physical performance battery (SPP)) were independent of sarcopenia. However, body mass index, muscle strength, and quality of life (according to the EQ-5D questionnaire) were significantly lower in subjects with sarcopenia [14].

Another study involving 17,476 male and female showed that obesity and sarcopenia were associated with gonarthrosis in the elderly [31]. The risk of OA was higher in men with sarcopenic obesity than in men with non-sarcopenic obesity. In women, the risk of knee OA was high in both obese groups.

The severity of OA is aggravated with sarcopenia presence and metabolic syndrome or insulin resistance [13].

However, not all researchers support the point of view about the direct effect of sarcopenia on the development of OA or opposite. Based on an ana- lysis of four prospective and one crossectional studies, which included 4231 patients (mean age 62 years) in terms of weight, height and body mass index and assessment of gonarthrosis according to the KellgrenLawrence scale, the authors were unable to support the hypothesis of a direct effect of sarcopenia on development OA due to the lack of clinical research regarding on measurements and instruments to compare sarcopenia and OA [32].

Effect of sarcopenia on the results of total knee arthroplasty in patients with osteoarthritis

Due to the fact that sarcopenia is often common in patients with osteoarthritis, researches are being conducted to study the dynamics of the recovery period after total knee arthroplasty. There are two prospective studies showing that after total hip or knee arthroplasty in patients with sarcopenia the length of hospital stay is increased, the percentage of complications, falls, fractures of the lower extremities, and repeated hospitalization are increased [33-35].

There is a study of the effect of sarcopenia on the clinical outcome after surgery in patients with knee OA [35]. The authors revealed that patients with sarcopenia had worse WOMAC-PF scores compared to patients without sarcopenia, in addition, the severity of pain in patients with sarcopenia according to the WOMAC scale was more severe.

However, there is also a study where, in a comparative assessment of 58 women with- and without sarcopenia after surgery in both groups was revealed an increase in walking speed and muscle strength [8]. However, no significant differences were found between the groups.

\section{Prevention and treatment}

There are no specific evidence-based methods of treatment for sarcopenia, as the primary point is prevention. The data available in the literature are based on the results of a study of the mechanisms common for the development of sarcopenia and osteoarthritis and have only advisory nature. Based on the contribution of the generation of reactive oxygen species (ROS) to the development of sarcopenia and osteoarthritis, experimental studies have shown that a decrease in above-mentioned indicator counteracts telomere shortening, increases the survival of muscle cells and restores muscle homeostasis [25], as a result delays the development of sarcopenia [21]. In the perspective, a potential therapeutic target for the protection of skeletal muscles from age-related accumulation of ROS may be the restoration of redox homeostasis through the effect on Nrf2 [26].

Exercises of various modes are recommended as an effective strategy for maintaining muscle health, 
as a result the regulation of metabolic processes at the molecular, cellular and organism levels is possible $[36,37]$. In experimental studies in mice, it has been shown that physical activity aimed at muscle strengthening helps to remove free radicals that are the products of oxidative stress [37]. In addition, the authors found that exercise increased lifespan by altering muscle transcriptome and metabolism, modulating the expression of the Cisd 2 gene, which promotes longevity. Exercise are also stimulus for muscle protein biosynthesis by cells.

Adequate protein intake is important in the prevention of sarcopenia. ESCEO recommends a dietary protein intake of 1.0 to $1.2 \mathrm{~g} / \mathrm{kg}$ body weight per day [38].

In general, further studies of the cellular and molecular mechanisms of the connection between sarcopenia and OA are needed to expand the understanding of the common links of these conditions and to develop pharmacological and non-pharmacological methods of treatment.

\section{Conclusions}

Sarcopenia is considered an important geriatric syndrome, the manifestations are leaded to impaired quality of life and increased rates of mortality. The severity of sarcopenia can be influenced by many factors - a person's age, comorbidity, lifestyle, nutrition, etc. In this regard, an important direction of scientific research is to study the manifestation of sarcopenia in the conditions of various disorders in the body. Sarcopenia is frequently accompanied by OA. However, in current literature there are no fundamental scientific research on the connection and interdependence of OA and sarcopenia, which makes it impossible to assess it significantly. The available data indicate that the presence of these pathologies violates the quality of life of patients in terms of quality of life and physical activity, however, data on the effect of sarcopenia, including sarcopenic obesity, on the manifestation of pain in large joints are ambiguous. The mechanisms of cellular and molecular profiles specific to the association of these pathologies are actively investigated. Although there are common mechanisms in their development: the influence of reactive oxygen species, systemic chronic low-grade inflammation, myostatin expression, and BMR signaling pathways, they cannot be considered as universal biomarkers specific only to sarcopenia and OA. In general, sarcopenia and OA can be thought of as coexisting age-related diseases that jointly affect the quality and duration of life.
Conflict of interest. The authors declare the absence of conflict of interest.

\section{References}

1. Pickering M. E. Where two common conditions of aging meet: osteoarthritis and sarcopenia / M. E. Pickering, R. Chapurlat// Calcified Tissue International. - 2021. - Vol. 107 (3). P. 203-211. - DOI: 10.1007/s00223-020-00703-5.

2. Update on the role of muscle in the genesis and management of knee osteoarthritis / K. L. Bennell, T. V. Wrigley, M. A. Hunt [et al.] // Rheumatic Diseases Clinics of North America. - 2013. Vol. 39 (1). - P. 145-176. — DOI: 10.1016/j.rdc.2012.11.003.

3. Muscle weakness in hip osteoarthritis: a systematic review / A. Loureiro, P. M. Mills, R. S. Barrett // Arthritis Care \& Research. - 2013. - Vol. 65 (3). - P. 340-352. DOI: $10.1002 /$ acr.21806.

4. Effect of thigh strength on incident radiographic and symptomatic knee osteoarthritis in a longitudinal cohort / N. A. Segal, J. C. Torner, D. Felson [et al.] // Arthritis Care \& Research. 2009. - Vol. 61 (9). — P. 1210-1217. — DOI: 10.1002/art.24541.

5. Skeletal muscle wasting and its relationship with osteoarthritis: a mini-review of mechanisms and current interventions / E. Shorter, A. J. Sannicandro, B. Poulet, K. Goljanek-Whysall // Current Rheumatology Reports. - 2019. - Vol. 21 (8). Article ID: 40. — DOI: 10.1007/s11926-019-0839-4.

6. Sarcopenia: revised European consensus on definition and diagnosis. Writing Group for the European Working Group on Sarcopenia in Older People 2 (EWGSOP2), and the Extended Group for EWGSOP2 / A. J. Cruz-Jentoft, G. Bahat, J. Bauer [et al.] // Age Ageing. — 2019. — Vol. 48 (4). — Article ID: 601. - DOI: 10.1093/ageing/afz046.

7. Age-related changes in the structure and function of skeletal muscles / J. A. Faulkner, L. M. Larkin, D. R. Claflin, S. V. Brooks // Clinical and Experimental Pharmacology \& Physiology. — 2007. — Vol. 34 (11). — P. 1091-1096. DOI: $10.1111 / \mathrm{j} .1440-1681.2007 .04752 . x$.

8. End-stage knee osteoarthritis with and without sarcopenia and the effect of knee arthroplasty - a prospective cohort study / K. K. Ho, L. C. Lau, W. W. Chau [et al.] // BMC Geriatrics. - 2021. Vol. 21 (1). - Article ID: 2. —DOI: 10.1186/s12877-020-01929-6.

9. Tian S. Association of sarcopenic obesity with the risk of allcause mortality: a meta-analysis of prospective cohort studies / S. Tian, Y. Xu // Geriatrics \& Gerontology International. 2016. - Vol. 16 (2). - P. 155-166. — DOI: 10.1111/ggi.12579.

10. Cauley J. A. An overview of sarcopenic obesity / J. A. Cauley // Journal of Clinical Densitometry. - 2015. - Vol. 18 (4). P. 499-505. - DOI: 10.1016/j.jocd.2015.04.013.

11. The impact of sarcopenic obesity on knee and hip osteoarthritis: a scoping review / K. Godziuk, C. M. Prado, L. J. Woodhouse, M. Forhan // BMC Musculoskeletal Disorders. 2018. - Vol. 19 (1). — Article ID : 271. — DOI: 10.1186/ s12891-018-2175-7.

12. Roubenoff R. Sarcopenic obesity: the confluence of two epidemics / R. Roubenoff // Obesity Research. — 2004. Vol. 12 (6). - P. 887-888. - DOI: 10.1038/oby.2004.107.

13. Novel effects of sarcopenic osteoarthritis on metabolic syndrome, insulin resistance, osteoporosis, and bone fracture: the national survey / S. M. Chung, M. H. Hyun, E. Lee [et al.] // Osteoporosis International. - 2016. - Vol. 27 (8). - P. 2447-2457. DOI: $10.1007 / \mathrm{s} 00198-016-3548-0$.

14. Сафонова Ю. А. Саркопения у пациенток старшего возраста с остеоартритом крупных суставов / Ю. А. Сафонова, Е. Г. Зоткин // Научно-практическая ревматология. 2019. — № 57 (2). - C. 154-159. — DOI: 10.14412/19954484-2019-154-159.

15. Identifying patients with osteoarthritis at risk of sarcopenia using the SARC-F / M. Lovett, A. Negm, G. Ioannidis [et al.] // 
Canadian Geriatrics Journal. — 2021. — Vol. 24 (1). — P. 1-7. DOI: $10.5770 / \mathrm{cgj} .24 .479$.

16. Sarcopenia: etiology, clinical consequences, intervention, and assessment / T. Lang, T. Streeper, P. Cawthon [et al.] // Osteoporosis International. — 2010. - Vol. 21 (4). - P. 543-559. DOI: 10.1007/s00198-009-1059-y.

17. Lee S. Sarcopenic obesity is more closely associated with knee osteoarthritis than is nonsarcopenic obesity: a crosssectional study / S. Lee, T. N. Kim, S. H. Kim // Arthritis and Rheumatism. - 2012. — Vol. 64 (12). - P. 3947-3954. DOI: $10.1002 /$ art.37696.

18. Haseeb A. Immunopathogenesis of osteoarthritis / A. Haseeb, T. M. Haqqi // Clinical Immunology. — 2013. - Vol. 4146 (3). P. 185-196. — DOI: 10.1016/j.clim.2012.12.011.

19. Loeser R. F. Age-related changes in the musculoskeletal system and the development of osteoarthritis / R. F. Loeser // Clinics in Geriatric Medicine. - 2010. — Vol. 26 (3). - P. 371-386. DOI: $10.1016 /$ j.cger.2010.03.002.

20. Inflammation and sarcopenia: A systematic review and metaanalysis / G. Bano, C. Trevisan, S. Carraro [et al.] // Maturitas. — 2017. - Vol. 96. - P. 10-15. — DOI: 10.1016/j. maturitas.2016.11.006.

21. Picca A. Molecular mechanism and pathogenesis of sarcopenia: an overview / A. Picca, R. Calvani // International Journal of Molecular Sciences. - 2021. - Vol. 2 (6). - Article ID: 3032. — DOI: 10.3390/ijms22063032.

22. Budui S. L. The pathogenetic bases of sarcopenia / S. L. Budui, A. P. Rossi, M. Zamboni // Clinical Cases in Mineral and Bone Metabolism. - 2015. - Vol. 12 (2). - P. 22-26. DOI: $10.11138 / \mathrm{ccmbm} / 2015.12 .1 .022$.

23. Bolduc J. A. Reactive oxygen species, aging and articular cartilage homeostasis / J. A. Bolduc, J. A. Collins, R. F. Loeser // Free Radical Biology \& Medicine. - 2019. - Vol. 132. P. 73-82. — DOI: 10.1016/j.freeradbiomed.2018.08.038.

24. Osteoarthritis and telomere shortening/L. Kuszel, T. Trzeciak, M. Richter, M. Czarny-Ratajczak // Journal of Applied Genetics. - 2015. - Vol. 56 (2). - P. 169-176. - DOI: 10.1007/ s13353-014-0251-8.

25. Telomeres shorten in response to oxidative stress in mouse skeletal muscle fibers / A. T. Ludlow, E. E. Spangenburg, E. R. Chin [et al.] // The Journals of Gerontology. Series A, Biological Sciences and Medical Sciences. - 2014. - Vol. 69 (7). P. 821-830. — DOI: 10.1093/gerona/glt211.

26. Disruption of Nrf2/ARE signaling impairs antioxidant mechanisms and promotes cell degradation pathways in aged skeletal muscle / C. J. Miller, S. S. Gounder, S. Kannan [et al.] // Biochimica et Biophysica Acta. - 2012. - Vol. 1822 (6). P. 1038-1050. — DOI: 10.1016/j.bbadis.2012.02.007.

27. Bone Morphogenetic Proteins and myostatin pathways: key mediator of human sarcopenia / M. Scimeca, E. Piccirilli, F. Mastrangeli [et al.] // Journal of Translational Medicine. 2017. - Vol. 15 (1). — Article ID: 34. — DOI: 10.1186/ s12967-017-1143-6.
28. Myostatin serum concentrations are correlated with the severity of knee osteoarthritis / C. Zhao, Y. Shao, C. Lin [et al.] // Journal of Clinical Laboratory Analysis. - 2017. - Vol. 31 (5). Article ID: e22094. - DOI: 10.1002/jcla.22094.

29. MOST study. Risk of knee osteoarthritis with obesity, sarcopenic obesity, and sarcopenia / D. Misra, R. A. Fielding, D. T. Felson [et al.] // Arthritis \& Rheumatology. - 2019. Vol. 71 (2). - P. 232-237. — DOI: 10.1002/art.40692.

30. Sarcopenia in osteoarthritis and rheumatoid arthritis: The association with self-reported fatigue, physical function and obesity / L. Vlietstra, S. Stebbings, K. Meredith-Jones [et al.] // PLoS One. — 2019. — Vol. 14 (6). — Article ID: 0217462. DOI: 10.1371/journal.pone.0217462.

31. Relationships among Obesity, Sarcopenia, and Osteoarthritis in the Elderly / W. S. Jin, E. J. Choi, S. Y. Lee [et al.] // Lournal of Obesity \& Metabolic Syndrome. — 2017. — Vol. 26 (1). P. 36-44. - DOI: 10.7570/jomes.2017.26.1.36.

32. Sarcopenia and its relationship with osteoarthritis: risk factor or direct consequence? / R. Papalia, B. Zampogna, G. Torre [et al.] // Musculoskeletal Surgery. - 2014. - Vol. 98 (1). P. 9-14. - DOI: 10.1007/s12306-014-0311-6.

33. Comparative analysis on the effects of sarcopenia following primary total knee arthroplasty: A retrospective matched-control analysis / A. D. Ardeljan, T. S. Polisetty, J. Palmer [et al.] // The Journal of Knee Surgery. - 2020. — DOI: 10.1055/s0040-1713355.

34. Sarcopenia as a risk factor for prosthetic infection after total hip or knee arthroplasty / J. M. Babu, S. Kalagara, W. Durand [et al.] // The Journal of Arthroplasty. — 2019. — Vol. 34 (1). P. 116-122. - DOI: 10.1016/j.arth.2018.09.037.

35. Impact of sarcopenia on rehabilitation outcomes after total knee replacement in older adults with knee osteoarthritis / C. D. Liao, H. C. Chen, S. W. Huang, T. H. Liou // Therapeutic Advances in Musculoskeletal Disease. - 2021. - Vol. 13. - Article ID: 1759720X21998508. - DOI: 10.1177/1759720X21998508.

36. Sarcopenia: Molecular pathways and potential targets for intervention / J. Pascual-Fernandez, A. Fernández-Montero, A. Córdova-Martínez [et al.] // International Journal of Molecular Sciences. - 2020. - Vol. 21 (22). - Article ID: 8844. - DOI: 10.3390/ijms21228844.

37. Exercise and the Cisd 2 prolongevity gene: Two promising strategies to delay the aging of skeletal muscle / Y. C. Teng, J. Y. Wang, Y. H. Chi, T. F. Tsai // International Journal of Molecular Sciences. - 2020. — Vol. 21. - Article ID: 9059. - DOI: 10.3390/ijms21239059.

38. Beaudart C. Outcomes of the IOF-ESCEO sarcopenia working groups. WCO-IOF-ESCEO. / C. Beaudart : World Congress on Osteoporosis, Osteoarthritis and Musculoskeletal Diseases. - Springer, 2018. - P. 77-78.

39. Zamboni M. Sarcopenia and obesity / M. Zamboni, S. Rubele, A. P. Rossi // Current Opinion in Clinical Nutrition and Metabolic Care. - 2019. - Vol. 22 (1). - P. 13-19. DOI: $10.1097 / \mathrm{MCO} .0000000000000519$.

\title{
САРКОПЕНІЯ, САРКОПЕНІЧНЕ ОЖИРІННЯ ТА ОСТЕОАРТРОЗ
}

\author{
Н. В. Дєдух ${ }^{1}$, Н. В. Заверюха ${ }^{1}$, М. А. Бистрицька ${ }^{1}$, Н. М. Яковенчук ${ }^{2}$ \\ ${ }^{1}$ ДУ «Інститут геронтології ім. Д. Ф. Чеботарьова НАМН України», Київ \\ ${ }^{2}$ КНП СОР Сумська обласна клінічна лікарня \\ $\triangle$ Ninel Dedukh, Dr. Biol. Sci., Prof.: dedukh_ninel@ukr.net \\ $\checkmark$ Nataliia Zaverukha, MD: nataliyahryb@gmail.com \\ Maryna Bystrytska, MD: miroslava_br@ukr.net \\ $\triangle$ Nataliya Yakovenchuk, MD: nataliyayakovenchuk@ukr.net
}

